УДК 614.253.8-025.24-047.44(4)

\title{
Порівняльний аналіз європейських систем однорідних груп пацієнтів
}

\author{
I.M. Рогач, М.М. Смірнов, В.В. Жорник \\ kaf-socmed@uzhnu.edu.ua \\ Ужгородський національний університет, медичний факультет, кафедра соиіальної \\ медищини та гігієни, м. Ужгород, Україна
}

Реферат

У Європі залежно від способу реімбурсації існують дві базові моделі фінансування лікувальнопрофілактичних закладів, що надають стаціонарну допомогу в умовах систем однорідних груп пацієнтів: ретроспективні платежі за випадок госпіталізації та проспективне бюджетне асигнування. Кожна модель має свій вплив на діяльність закладів охорони здоров'я. Також існують різні методи розрахунку фактичної ставки оплати кожної групи. Узагальнено дана ставка дорівнює добутку значення групи і коефіцієнта грошового перетворення. Але і значення і коефіцієнт можуть відрізнятися залежно від країни і виражатися в різних величинах, що надалі змінює сукупність і інтенсивність стимулів діяльності закладів.

Метою роботи було вивчення моделей ретроспективних ОГП-заснованих платежів за випадок госпіталізації, їх імплементації та впливу на національні системи охорони здоров'я в п'яти європейських країнах, а саме: у Великій Британії, Франції, Німеччині, Польщі та Угорщині. Дані сучасної наукової літератури, щодо моделі ОГП-заснованих платежів за випадок госпіталізації, проаналізовано з використанням контент-аналізу, методу системного і порівняльного аналізу, а також бібліосемантичного методу вивчення відповідних наукових робіт.

У основній частині статті проаналізовано характеристики національних систем охорони здоров'я вищезазначених країн, а саме: джерела фінансування, особливості методів реімбурсації витрат закладів охорони здоров'я, досвід з імплементації однорідних груп пацієнтів та сучасні методи калькуляції фактичної ставки оплати випадків госпіталізації. Також, для кожної залученої у дослідження країни, було зазначено еволюцію певних показників діяльності національних систем охорони здоров'я в умовах однорідних груп пацієнтів. Окремо наведено розділ, в якому проаналізовано навмисні та ненавмисні наслідки, які необхідно очікувати та заздалегідь попереджувати при імплементації систем однорідних груп пацієнтів.

У результаті було визначено, що в досліджуваних країнах спостерігається послідовне скорочення ліжкових фондів і термінів госпіталізації з одночасним покращенням показників якості медичної допомоги населенню.

Ключові слова: фінансування, однорідні групи пацієнтів, ОГП, DRG, відшкодування витрат, стаціонарна допомога.

Comparative analysis of European systems of homogeneous patient groups

I.M. Rogach, M.M. Smirnov, V.V. Zhornyk

Uzhhorod National University, Medical Faculty, Department of Social Medicine and Hygiene, Uzhhorod

Abstract

In Europe, depending on the method of reimbursement, there are two basic models of financing of health care facilities that provide acute inpatient care under homogeneous patient groups: retrospective payments for hospitalization cases and prospective budgetary allocations. Each model has its own impact on activities of health care facilities. Also, different methods of calculating the actual rate of payment for each group exist. Generally, this rate is equal to the product of the value of the group and the rate of conversion. But both the valuesand the coefficients may differ depending on the country and be expressed in different quantities. This further changes the totality and the intensity of the institution incentives.

The purpose was to study models of retrospective DRG-based payments for hospitalization cases, their implementation and impact on national health systems in five European countries, namely in the United Kingdom, France, Germany, Poland and Hungary. Data from current scientific literature about the model of DRG-based payments have been analyzed using the content analysis, the method of systematic and comparative analysis, and the bibliosemantic method.

The main part of the article analyzes characteristics of national healthcare systems of the countries mentioned above: the sources of funding, the features of reimbursement methods for healthcare facilities, the experience of implementation of homogeneous patient groups, and current methods of calculating the actual rate of hospitalization case. Also, for each country of this study, the evolution of certain indices of national health care systems under homogeneous patient groups was noted. A separate section is provided to analyze the intended and unintended consequences that should be anticipated and prevented during the implementation of homogeneous patient group systems.

As a result, it was determined that in the countries studied there was a consistent reduction in bed funds and length of stay, while improving the quality of health care.

Key words: financing, homogeneous patient groups, OGP, DRG, reimbursement, inpatient care. 
Вступ. У Свропі залежно від способу реімбурсації існують дві базові моделі фінансування лікувально-профілактичних закладів (ЛПЗ), що надають стаціонарну допомогу в умовах систем однорідних груп пацієнтів (ОГП): ретроспективні ОГП-засновані платежі за випадок госпіталізації і проспективне ОГП-засноване бюджетне асигнування.

Теоретично, порівняно з ОГП-заснованим бюджетним асигнуванням ОГП-засновані платежі за випадок госпіталізації забезпечують більш сильні стимули для ЛПЗ за рахунок того, що зв'язок між наданням лікарняних послуг i відшкодуванням витрат $є$ більш прямим і прозорим. У такій моделі керівництво ЛПЗ точно знає які обсяги фінансування воно може очікувати, надаючи певний набір послуг конкретному пацієнту. I навпаки, в системах ОГП-заснованого бюджетного асигнування керівництво ЛПЗ знає тільки те, що надання певного набору послуг конкретним пацієнтам протягом року збільшить бюджет на наступний рік, але точний загальний розмір виплат за конкретну ОГП залишається невідомим [1].

Саму ж фактичну ставку оплати випадку госпіталізації європейські країни з різними національними системами ОГП обчислюють різними способами. Узагальнено, дана ставка дорівнює добутку значення ОГП і коефіцієнта грошового перетворення (КГП) [2]. Але і значення ОГП і КГП можуть відрізнятися в залежності від країни і виражатися в різних величинах, що надалі змінює сукупність і інтенсивність стимулів ЛПЗ, що мають безпосередній вплив на стан національних систем охорони здоров'я.

Приймаючи до уваги той факт, що фінансування стаціонарної допомоги на основі систем ОГП має світове визнання і на даний момент імплементоване в багатьох європейських країнах, неможливо не розглядати можливість впровадження даної моделі як майбутньої моделі фінансування вторинної і третинної ланок медичної допомоги реформованої української системи охорони здоров'я. Тому з огляду на існування різних класифікацій, способів реімбурсації та визначення фактичної ставки оплати, ми вважаємо необхідним вивчення національних систем ОГП певних країн. Але у вітчизняній літературі досі, на нашу думку, питання фінансування стаціонарної допомоги на основі систем ОГП залишається "terra incognita".

Мета долідження. Вивчення моделі ОГПзаснованих платежів за випадок госпіталізації в європейських країнах, іiі імплементації та впливу на національні системи охорони здоров'я.

Матеріали та методи. Дані сучасної наукової літератури щодо моделі ОГП-заснованих платежів за випадок госпіталізації проаналізовано $з$ використанням контент-аналізу, методу системного і порівняльного аналізу, а також бібліосемантичного методу вивчення відповідних наукових робіт. Пошук джерел англійською, французькою, російською, українською, польською та німецькою мовами проводився в наступних інформаційних базах i пошукових системах: PubMed, ResearchGate i Google Scholar - відповідно до ключових слів: DRG, diagnosis related groups, implementation, reimbursement, КСГ.

Результати досліджень та їх обговорення. Для аналізу нами були обрані нижчеперераховані країни, з огляду на такі міркування:

- Великобританія, Франція і Німеччина $\epsilon$ класичними прикладами провідних європейських країн із високим рівнем доходів, що мають тривалу історію функціонування в умовах систем ОГП;

- Польща та Угорщина, межуючи з Україною, входили до складу країн Варшавського договору і на момент імплементації ОГП були країнами із середнім рівнем доходів, якою на даний момент є Україна.

Також, з огляду на те, що країни імплементували системи ОГП у різний час, і вартість медичних послуг неодмінно зросла в порівнянні 3 1990-ми роками, ми вважаємо за доцільне надати показники діяльності систем охорони здоров'я за більш сучасний відрізок часу, коли всі країни або вже функціонували в умовах систем ОГП, або перебували в процесі їх впровадження.

Таблиця 1

Порівняння систем ОГП

\begin{tabular}{|l|c|c|c|c|c|}
\hline \multicolumn{1}{|c|}{ Країна } & Велика Британія & Франція & Німеччина & Польща & Угорщина \\
\hline Назва ОГП & HRG & GHM & G-DRG & JGP & HBC \\
\hline $\begin{array}{l}\text { Основа } \\
\text { ОГП }\end{array}$ & нема & HCFA-DRG & AR-DRG & HRG & HCFA-DRG \\
\hline $\begin{array}{l}\text { Рік введен- } \\
\text { ня }\end{array}$ & 1993 & 2004 & 2003 & 2009 & 1993 \\
\hline $\begin{array}{l}\text { Значення } \\
\text { ОГП }\end{array}$ & Вихідні тарифи & $\begin{array}{c}\text { Вихідні тари- } \\
\text { фи }\end{array}$ & Відносна вага & Бали & Відносна вага \\
\hline КГП & $\begin{array}{c}\text { Коефіцієнт } \\
\text { поправки }\end{array}$ & $\begin{array}{c}\text { Коефіцієнт } \\
\text { поправки }\end{array}$ & Базова ставка & $\begin{array}{c}\text { Вартість } \\
\text { бала }\end{array}$ & Базова ставка \\
\hline
\end{tabular}




\section{Велика Британія і HRG.}

Велика Британія витрачає близько 8\% валового внутрішнього продукту (ВВП) на охорону здоров'я: $87 \%$ витрат припадає на державний сектор, і всього 13\% на приватний. Для порівняння, в Євросоюзі середня питома вага витрат на приватний сектор дорівнює $23 \%$. Приблизно $60 \%$ доходів ЛПЗ Англії - ОГП-засновані платежі за випадок госпіталізації, інша частина надходить із загальнодержавного бюджету і додаткових джерел [1]. Національна служба здоров'я (англ. National Health Service - NHS) фінансується за рахунок загального оподаткування $(80,3 \%)$, внесків у національне страхування $(18,4 \%)$ і безпосередніх платежів пацієнтів за лікарські призначення, стоматологічні та оптометричні послуги (1,3\%) [3]. NHS знаходиться в юрисдикції Міністерства Здоров'я (англ. Department of Health), головою якого є Держсекретар з питань здоров'я (англ. Secretary of State for Health) [4].

Більшість послуг NHS надаються населенню державними провайдерами. У секторі первинної медичної допомоги, незважаючи на те, що фінансування надходить із державних фондів, лікарі загальної практики зазвичай об'єднуються в групові практики, де кожен лікар є приватним підприємцем. У сфері спеціалізованої медичної допомоги ЛПЗ об'єднуються в юридичні особи, відомі як трасти NHS [4].

Англійська версія ОГП називається HRG (англ. Healthcare Resource Groups, «Ресурсні групи охорони здоров'я») [5] і була імплементована в 1993 році для:

- еталонного тестування, забезпечуючи основу для порівняльної оцінки ефективності ЛПЗ;

- оптимізації управління внутрішніми ресурсами ЛПЗ;

- стандартизації методів розподілу витрат, які в підсумку мали призвести до еволюції договірних відносин між ЛПЗ і NHS.

За час свого існування HRG була кілька разів змінена. Поточною версією є HRG4, яка щорічно оновлюється і для кодування використовує діагнози з МКX-10, а також процедури з OPCS4.8. У 2002-2003 роках була представлена модель ОГП-заснованих платежів за випадок госпіталізації - PbR, яка замінила проспективне бюджетне асигнування [6].

Велика Британія використовує вихідні тарифи в якості значення HRG для визначення фактичної ставки оплати випадку госпіталізації. Вихідні тарифи мають грошове вираження і розраховуються безпосередньо 3 середніх витрат на лікування пацієнтів у рамках однієї HRG з урахуванням інфляції. Також існують різні вихідні тарифи однієї HRG для різних спеціальностей: невідкладної допомоги, педіатричної та ортопедичної служби. Надалі вихідні тарифи помно- жуються на КГП - коефіцієнт поправки, або фактор ринкових сил (англ. Market Forces Factor), який враховує певні характеристики ЛПЗ (такі як вищий рівень заробітної плати в регіоні або наявність у лікарні статусу клінічної) $[4,7]$.

У Великій Британії згідно з бюджетом обмежуються виплати тільки за ургентну госпіталізацію: в поточному році оплачується повна вартість за кожен випадок до досягнення порогу, заснованого на активності ЛПЗ у попередньому році, і 50\% вартості за випадки вище даного порогу. Для планової госпіталізації порогове значення не встановлено, і ЛПЗ можуть підвищувати активність без попереднього схвалення у вищих інстанціях [8].

У період із 2006 по 2012 рік (табл. 1, 2) у Великій Британії кількість стаціонарних ліжок зменшилася на 20\%, терміни госпіталізації незначно зменшилися на $7,8 \%$, дитяча смертність знизилася на $18 \%$, смертність від раку знизилася на $4,2 \%$, кількість консультацій спеціалістів на душу населення практично не відхилялась від значення 5,0, загальні витрати на охорону здоров'я на душу населення збільшилися з \$2936 до $\$ 3289$, очікувана тривалість життя при народженні збільшилася на 1 рік [9].

\section{Франція і GHM.}

Франція виділяє близько 11\% ВВП на сектор охорони здоров'я, що є заснований на соціальному страхуванні, фонд якого поповнюється внесками, що вилучаються безпосередньо 3 заробітної плати у вигляді податків. Більшість внесків надходить у Національні каси медичного страхування (фр. Caisse nationale d'assurance maladie). Із загального обсягу фінансування ЛПз $91 \%$ витрат забезпечують каси соціального медичного страхування, 5\% - додаткове приватне медичне страхування (фр. Mutuelle santé) i ще $4 \%$ - інші джерела (Міністерство освіти і т.д.). Щодо методу фінансування, $80 \%$ доходів ЛПЗ Франції - ОГП-засновані платежі за випадок госпіталізації, інша частина надходить із додаткових джерел і загальнодержавного бюджету [1].

Первинна ланка часто представлена приватною i, як правило, на відміну від Великої Британії, індивідуальною практикою. Стаціонарна i спеціалізована амбулаторна допомога надається як у державних ЛПЗ, так і в приватних комерційних i некомерційних ЛПз. Державні ЛПз складають $60 \%$ всіх лікарень і вміщують $65 \%$ всіх стаціонарних ліжок. Варто відзначити, що до впровадження систем ОГП у Франції державний і некомерційний приватний сектори фінансувалися за рахунок бюджетного асигнування, а комерційний сектор - на основі діяльності [10].

Перша французька система класифікації пацієнтів, GHM (фр. Groupes homogènes des malades, «Однорідні групи пацієнтів»), була за- 
пропонована в 1986 році вибірці державних ЛПЗ для оптимізації опису діяльності ЛПЗ. У 1991 році збір та подання даних про діяльність ЛПЗ із використанням GHM стали обов'язковими для всіх державних ЛПЗ. Ці дані використовувалися для порівняння продуктивності ЛПЗ і внесення коригувань у загальнодержавні бюджети. Дані зміни впровадили в приватний сектор тільки в 1998 році. В кінцевому підсумку, модель фінансування ЛПЗ на основі GHM було поступово імплементовано в період з 2004 по 2008 рк [10, $11]$.

Цілями імплементації GHM у Франції стали підвищення ефективності, створення рівних умов для платежів державним і приватним ЛПЗ, підвищення прозорості діяльності та управління ЛПЗ і поліпшення якості медичної допомоги [10].

Спочатку французька GHM була заснована на американській версії (HCFA-DRG). Пізніше вона була кардинально модифікована. На даний момент використовується версія GHM11b, яка включає 2300 груп. Для класифікації пацієнтів використовується національна база даних - Програма медикалізації інформаційних систем (фр. Programme de médicalisation des systèmes d'information), а для розрахунку значень GHM Національне вивчення витрат (фр. Étude nationale de coûts à méthodologie commune) [11, 12].

Для визначення фактичної ставки оплати випадку госпіталізації, як і в Великій Британії, використовуються вихідні тарифи, які встановлюються на національному рівні для державних i приватних ЛПЗ. Державні тарифи включають усі послуги, приватні ж, навпаки, позбавлені деяких медичних послуг, які оплачуються окремо безпосередньо пацієнтом. Таким чином, приватні лікарні можуть стягувати додаткову плату за більш комфортне розміщення і додаткові послуги. Лікарі 3 приватною практикою в державних лікарнях також можуть стягувати додаткову плату з пацієнтів [8].

На відміну від Сполученого королівства, у Франції вихідні тарифи коригуються 3 урахуванням особливостей загальнодержавного бюджету. КГП є також коефіцієнт поправки, який відображає історичні шаблони витрат ЛПЗ $[1,8]$.

У Франції в період із 2006 по 2012 рік (табл. 1, 2) кількість стаціонарних ліжок зменшилася на 11,3\%, терміни госпіталізації зменшилися на 10,5\%, дитяча смертність знизилася на 7,9\%, смертність від раку знизилася на 6,5\%, кількість консультацій фахівців на душу населення практично не відхилялася від значення 6,7, загальні витрати на охорону здоров'я на душу населення збільшилися з \$3411 до \$4288, очікувана тривалість життя при народженні збільшилася на 1,2 року [9]

\section{Німеччина i G-DRG}

Близько 10,4\% ВВП Німеччини витрачається на охорону здоров'я. Трьома основними джерелами є національне медичне страхування (57,5\% від загальних витрат на охорону здоров'я), приватне медичне страхування (9,3\%) і безпосередні платежі пацієнтів $(13,5 \%)$. Приблизно $80 \%$ доходів ЛПУ Німеччини - ОГП-засновані платежі за випадок госпіталізації, інша частина надходить із загальнодержавного бюджету і додаткових джерел [13].

Із 2009 року медичне страхування $\epsilon$ обов'язковим у Німеччині. Близько $86 \%$ населення Німеччини охоплено національним медичним страхуванням (нім. Gesetzliche Krankenv rsicherung - GKV), 10\% - приватним медичним страхуванням (нім. Private Krankenversicherung - $P K V$ ), 4\% відносяться до спеціальних станів. Система GKV заснована на внесках, що вилучаються безпосередньо з заробітної плати у вигляді податків, і складається 3 лікарняних кас. Доступ до $\mathrm{PKV}$ з'являється при наявності протягом трьох років поспіль доходу, що перевищує певний поріг (наприклад, €49950 на рік, або €4162,5 на місяць в 2010 році) [8, 13].

Цікавим $є$ те, що в Німеччині на законодавчому рівні чітко розділені амбулаторна і стаціонарна допомога. Планування, розподіл ресурсів і фінансування здійснюються окремо в кожному секторі. Відшкодування витрат ЛПЗ на вторинному етапі надходить із двох різних джерел: державний бюджет підтримує функціонування інфраструктури в той час, як поточні витрати відшкодовуються лікарняними касами та PKV через систему ОГП. 49\% ліжкових фондів Німеччини належать державним ЛП3, 35\% - некомерційним і 16\% - комерційним приватним ЛПЗ [7, 13].

Імплементація національної системи G-DRG (англ. German diagnosis related groups, «Німецькі зв'язані діагнозами групи») почалася в 2003 році на основі австралійської системи версії 4.1 (англ. Australian refined diagnosis related groups - $A R-D R G)$. G-DRG використовує кодування захворювань за німецькою версією МКХ-10 і процедур за німецькою версією OPS. Від часу впровадження системи число груп збільшилося з 664 у 2003 році до 1200 у 2010 році [7, 13, 14]. Цілями впровадження системи G-DRG в Німеччині були:

- заміна старої системи реімбурсації для більш придатного та справедливого розподілу ресурсів;

- полегшення точного та прозорого вимірювання кількості випадків госпіталізації і якості послуг, що надаються лікарнями;

- покращення документообігу та підвищення управлінського потенціалу. 
У Німеччині використовується відносна вага як значення G-DRG і базові ставки як КГП для визначення фактичної ставки оплати випадку госпіталізації. Відносна вага кожної G-DRG i єдина базова ставка на федеральному рівні розраховуються Інститутом системи оплати лікарняних послуг (нім. Institut für das Entgeltsystem im Krankenhaus). Але до недавнього часу референтні значення базових ставок визначалися місцевими органами самоврядування і були унікальними для кожної федеративної одиниці Німеччини - Землі (нім. Länder). На території цих Земель кожний ЛПЗ мав, зі свого боку, власну ставку, що до 2010 року повинна була прийняти загальноземельне значення. Дана стратегія забезпечила поступовий перехід до стандартизованих значень. Загальний бюджет на G-DRG лімітований, і в умовах перевищення встановленого порогу більше, ніж на $35 \%$, базова ставка може бути знижена $[8,13,15]$.

Система G-DRG застосовується до всіх ЛПЗ, незалежно від форм власності, і майже до всіх пацієнтів, незалежно від того, чи $є$ вони членами GKV або PKV системи. PKV може включати доплати за індивідуальні палати й інші додаткові послуги ЛПЗ [14].

У період із 2006 по 2012 роки (табл. 1, 2) кількість стаціонарних ліжок у Німеччині залишалась незмінною, терміни госпіталізації зменшилися на $10,3 \%$, дитяча смертність знизилася на $13,2 \%$, смертність від раку знизилась на 5,6\%, кількість консультацій фахівців на душу населення трохи збільшилась, загальні витрати на охорону здоров'я на душу населення збільшилися з \$3572 до \$4811, очікувана тривалість життя при народженні збільшилась на 1 рік [9].

\section{Польща і JGP.}

У Польщі загальні витрати на галузь охорони здоров'я становлять $6,6 \%$ ВВП. Державні витрати становлять приблизно $72 \%$ і засновані на внесках на обов'язкове соціальне медичне страхування, що стягуються з заробітної плати. Витрати приватного сектора становлять $24 \%$ і в основному складаються 3 безпосередніх платежів пацієнтів [16]. 3 точки зору реімбурсації, понад $60 \%$ доходів ЛПЗ Польщі - ОГП-засновані платежі за випадок госпіталізації, інша частина надходить із загальнодержавного бюджету і додаткових джерел [1].

Основним покупцем медичних послуг для всіх членів системи соціального медичного страхування є Національний фонд здоров'я (пол. Narodowy Fundusz Zdrowia - NFZ). Зі свого боку, Міністерство охорони здоров'я розробляє національну політику в галузі охорони здоров'я та займається іiї регулюванням, а територіальні органи влади керують державними ЛПЗ і розроб- ляють стратегії зміцнення здоров'я на місцевому рівні [17].

У 1990-х роках система охорони здоров'я в посткомуністичній Польщі, як і в пострадянській Україні, зіткнулася з різким скороченням державного фінансування в умовах розвиненої інфраструктури охорони здоров'я і великої пільгової програми, що були створені попередньою владою. I хоча de jure в той час більшість функцій уряду залишилися без змін, de facto ці функції були нездійсненні, що призвело до появи неофіційного ринку послуг і корупції [18].

Для створення «здорових» ринкових умов у 1999 році була введена страхова медицина і оплата на основі діяльності, визначеної «Каталогом продуктів охорони здоров'я». Але проблемою даної моделі була недостатня прозорість. У цей же час було проведено кілька регіональних пілотних проектів впровадження адаптованої австрійської системи LFK (нім. Leistungsorientierte Krankenanstaltenfinanzierung) [16].

Тільки в 2007 році була представлена польська система JGP (пол. Jednorodne Grupy Pacjentów, «Однорідні групи пацієнтів»), яка була заснована на британській HRG3.5. Для кодування діагнозів використовувалася МКХ10, а процедур - польська версія МКБ-9. У 2008 році почалася її імплементація для класифікації пацієнтів, а $з$ січня 2009 року JGP почала використовуватись для реімбурсації витрат державних і приватних ЛПЗ, які підписали контракти 3 NFZ. JGP була введена для оптимізації розподілу коштів та ресурсів, а також для забезпечення більш прозорих умов надання послуг $[2$, $16,19]$.

Польща є однією $з$ небагатьох країн, у яких значення JGP виражаються у вигляді балів, які помножуються на їх вартість (КГП), однакову для всієї країни. NFZ разом із Міністерством охорони здоров'я визначають вартість балу в залежності від доступного національного лікарняного бюджету $[1,8]$. Польська система JGP постійно оновлюється, і з часом були додані реабілітаційні групи неврологічних і кардіологічних пацієнтів.

У період із 2006 по 2012 роки (табл. 1, 2) кількість стаціонарних ліжок лишилась незмінною $-6,5$ на 1 тис. населення, терміни перебування в стаціонарі зменшилися на $10,5 \%$, дитяча смертність знизилась на $23,3 \%$, смертність від раку знизилась на $8,1 \%$, кількість консультацій фахівців на душу населення трохи збільшилася з 6,6 до 7,0, загальні витрати на охорону здоров'я на душу населення збільшилися з $\$ 935$ до $\$ 1540$, очікувана тривалість життя при народженні збільшилася на 1,2 року [9]. 


\section{Угорщина і НВС.}

Угорщина домоглася успішного переходу від централізованої інтегрованої системи охорони здоров'я - радянської моделі Семашко - до ринкової моделі «постачальника-покупця», що передбачає методи оплати, засновані на результатах діяльності ЛПЗ [20].

Охорона здоров'я Угорщини в значній мірі фінансується (65\%) за рахунок соціального медичного страхування. Внески виходять 3 податків, об'єднуються на національному рівні і регулюються Адміністрацією національного фонду медичного страхування (угор. Országos Egészségbiztosítási Pénztár - OEP), яка в свою чергу знаходиться в юрисдикції Державного секретаpiaту 3 охорони здоров'я (угор. Egészségügyért Felelős Államtitkárság), який входить до складу Міністерства національних ресурсів (угор. Emberi Erőforrások Minisztériuma). ОЕР укладає контракти $з$ державними ЛПЗ, які надають більшість стаціонарних послуг. Що ж стосується приватних джерел, то їх більша частина припадає на безпосередні платежі пацієнтів, значну частину яких можна віднести до неформальних платежів із «власної кишені» [21], які є глибоко вкоріненою характеристикою посткомуністичної системи охорони здоров'я [20].

У останній роки в середньому 7-8\% ВВП витрачається на галузь охорони здоров'я, при цьому витрати на державний сектор становлять в середньому 70\% від загальних витрат. Історично обсяги фінансування були нестабільними протягом багатьох років із кількома хвилями зростання, за якими слідували більш тривалі періоди стримування витрат і скорочення бюджету [20].

Угорщина, як і Польща, будучи посткомуністичною країною, зіткнулася зі схожими проблемами на початку 1990-х років. Для їх вирішення перший пілотний проект ОГП в Угорщині було здійснено ще в 1987 році, але загальнодержавна імплементація почалася тільки в 1993 році. Спочатку система ОГП в Угорщині була заснована на американській версії HCFA-DRG, але в пода- льшому була відкоригована і названа НВС (угор. Homogén Betegségcsoportok, «Групи однорідних захворювань»). Система НВС була розроблена i управляється Інформаційним центром охорони здоров'я. Основними цілями, пов'язаними із впровадженням системи НВС в Угорщині, були політика стримування витрат на охорону здоров’я і підвищення ефективності ЛПЗ [2].

У середині 1990-х років кодування було змінено на МКХ-10, а ще пізніше були додані хірургічні групи і групи стаціонарної психіатричної допомоги [22].

Як значення НВС в Угорщині використовується відносна вага, що координується Комітетом 3 оновлення платіжних кодів. Базові ставки НВС спочатку були специфічними для конкретних ЛПЗ, але поступово до 1998 року були введені національні базові ставки, які тепер встановлюються проспективно щороку [23, 24].

У 2004 році в Угорщині були введені «контракти за обсягом роботи». Кількість випадків госпіталізації 2003 року було встановлено як еталон, і 98\% від зазначеного обсягу відшкодовувалися ЛПУ за повною ставкою до 2006 року. Додаткові ж випадки відшкодовувалися за зниженою ставкою (від 60\% до 10\%). Із 2006 року всього 95\% обсягу 2003-го року відшкодовувалися повністю, а додаткові випадки більше не підлягали реімбурсації [2], що призвело до збільшення часу очікування пацієнтів [23]. Дана політика обмеження бюджету ведеться і до цього дня.

У період із 2006 по 2012 рік (табл. 1, 2) кількість стаціонарних ліжок зменшилася на $12,5 \%$, терміни госпіталізації зменшилися на 14,8\%, дитяча смертність знизилася на $15 \%$, смертність від раку змінилася незначно, кількість консультацій фахівців на душу населення зменшилася на 7,8\%, загальні витрати на охорону здоров'я на душу населення збільшилися 3 \$1513 до $\$ 1803$, очікувана тривалість життя при народженні збільшилася на 1,7 року [9].

Таблиця 2

Показники діяльності систем охорони здоров’я (частина 1) [9]

\begin{tabular}{|l|c|c|c|c|c|c|}
\hline \multicolumn{1}{|c|}{ Показник } & \multicolumn{2}{c|}{$\begin{array}{c}\text { Кількість ліжок, } \\
\text { на 1 тис. нас. }\end{array}$} & \multicolumn{2}{c|}{$\begin{array}{c}\text { Сроки госпіталізації, } \\
\text { ліжко-днів }\end{array}$} & \multicolumn{2}{c|}{$\begin{array}{c}\text { Кількість консультацій } \\
\text { спеціалістів per capita }\end{array}$} \\
\hline Рік & 2006 & 2012 & 2006 & 2012 & 2006 & 2012 \\
\hline Велика Британія & 3,5 & 2,8 & 6,4 & 5,9 & 5,1 & $5,0 *$ \\
\hline Франція & 7,1 & 6,3 & 7,6 & 6,8 & 6,8 & 6,7 \\
\hline Німеччина & 8,3 & 8,3 & 8,7 & 7,8 & 7,9 & 9,7 \\
\hline Польща & 6,5 & 6,5 & 7,6 & 6,8 & 6,6 & 7,0 \\
\hline Угорщина & 8,0 & 7,0 & 6,1 & 5,2 & 12,8 & 11,8 \\
\hline
\end{tabular}

* у 2009 році 
Показники діяльності систем охорони здоров'я (частина 2) [9]

\begin{tabular}{|l|c|c|c|c|c|c|c|c|}
\hline \multicolumn{1}{|c|}{ Показник } & \multicolumn{2}{|c|}{$\begin{array}{c}\text { Смертність но- } \\
\text { вонароджених, } \\
\text { на 1 тис. живих } \\
\text { новонароджених }\end{array}$} & \multicolumn{2}{|c|}{$\begin{array}{c}\text { Смертність від } \\
\text { раку, на 100 } \\
\text { тис. нас. }\end{array}$} & $\begin{array}{c}\text { Витрати на охо- } \\
\text { рону здоров’я per } \\
\text { capita, } \$\end{array}$ & $\begin{array}{c}\text { Очікувана трива- } \\
\text { лість життя при на- } \\
\text { родженні, років }\end{array}$ \\
\hline Рік & 2006 & 2012 & 2006 & 2012 & 2006 & 2012 & 2006 & 2012 \\
\hline Велика Британія & 5,0 & 4,1 & 236,2 & $226,3 *$ & 2936 & 3289 & 77,8 & 78,7 \\
\hline Франція & 3,8 & 3,5 & 219,1 & $204,8 \S$ & 3411 & 4288 & 80,9 & 82,1 \\
\hline Німеччина & 3,8 & 3,3 & 213,5 & 201,6 & 3572 & 4811 & 77,7 & 78,7 \\
\hline Польща & 6,0 & 4,6 & 261,5 & 240,3 & 935 & 1540 & 79,8 & 81,0 \\
\hline Угорщина & 5,7 & 4,9 & 291,9 & 293,3 & 1513 & 1803 & 73,5 & 75,2 \\
\hline
\end{tabular}

* у 2010 році, § у 2011 році

\section{Наслідки впровадження систем ОГП.}

Поряд з очікуваними навмисними наслідками імплементації систем ОГП, такими як збільшення ефективності і якості стаціонарної допомоги населенню, забезпечення прозорості діяльності ЛПЗ, стандартизація документообігу та стимуляція управлінського потенціалу, існують і ненавмисні наслідки, про які не варто забувати. До них відносяться «відбір вишеньок» (англ. «Cherry picking»), відсіювання пацієнтів, надлишкове кодування, надмірні призначення і часті повторні госпіталізації.

«Відбір вишеньок» і відсіювання можливі в тому випадку, коли в одній ОГП присутній великий розкид у витратах на різних пацієнтів. 3 огляду на те, що оплата всіх випадків госпіталізації однієї групи однакова, ЛПЗ вигідно вибирати більш високооплачуваних (БВО) пацієнтів і, як наслідок, уникати решту.

Надмірне кодування передбачає збільшення доходу ЛПЗ за рахунок переміщення пацієнтів у БВО групи шляхом кодування додаткових діагнозів. Також ЛПЗ можуть змінювати внутрішні шаблони і протоколи лікування пацієнтів, надаючи послуги, які переміщують пацієнтів у БВО групи. I на останок, ЛПЗ можуть повторно гос- піталізувати пацієнтів для надання послуг, що можна забезпечити в амбулаторних умовах.

Але необхідно розуміти, що при правильній гармонійнії організації груп і умов відшкодування витрат, належному контролі діяльності ЛПЗ і якості наданої допомоги, а також наявності зовнішнього аудиту можливість виникнення вищевказаних небажаних наслідків зводиться до мінімуму [25].

Висновки. Більшість країн даного дослідження вирішило не створювати національну систему ОГП з нуля, а перетворити під свої потреби вже існуючу. Також в країнах спостерігається послідовне скорочення ліжкових фондів і термінів госпіталізації без негативного ефекту на якість наданої медичної допомоги, оскільки значення показників дитячої смертності та очікуваної тривалості життя при народженні, як індикаторів якості системи охорони здоров'я, поліпшуються.

Перспективи подальших досліджень полягають у продовженні вивчення даної теми, розробці ефективної, якісної та інноваційної національної системи ОГП в Україні та створенні інтегрованої моделі фінансування стаціонарної допомоги, заснованої на даній системі.

Інформація про конфлікт інтересів. Автори заявляють про відсутність конфлікту інтересів.

Інформація про фінансування. Автори заявляють про відсутність третіх сторін як джерел підтримки даного дослідження.

Особистий внесок кожного автора у виконання роботи. Кожен з авторів займався пошуком та аналізом літературних джерел, написанням рукопису та його редагуванням.

\section{Список використаної літератури}

1. Busse R, Geissler A, Quentin W, Wiley M. Diagnosis-related Groups in Europe: Moving Towards Transparency, Efficiency and Quality in Hospitals. Glasgow: Open University Press; 2011. 490 p.

2. Mathauer I, Wittenbecher F. DRG-based payments systems in low-and middle-income countries: Implementation experiences and challenges. World Health Organization; 2012. Report No.: HSS/HSF/DP. E. 10.2.

3. Hawe E. Compendium of health statistics [Internet]. Office of Health Economics; 2009. 289 p. (000235). Available from: https://ideas.repec.org/b/ohe/monogr/000235.html

4. Mason A, Ward P, Street A. England: the healthcare resource group system. In: Diagnosis-related groups in Europe: moving towards transparency, efficiency and quality in hospitals. Glasgow: Open University Press; 2011. p. 197-220. 
5. Anthony P. Healthcare resource groups in the NHS: a measure of success. Public Finance Account. $1993 ;(23): 8-10$.

6. Health D of. Reforming NHS financial flows: Introducing payment by results. Department of Health London; 2002.

7. O’Reilly J, Busse R, Häkkinen U, Or Z, Street A, Wiley M. Paying for hospital care: the experience with implementing activity-based funding in five European countries. Health Econ Policy Law. 2012 Jan $5 ; 7(1): 73-101$

8. Health Systems Institutional Characteristics: A Survey of 29 OECD Countries [Internet]. 2010 Apr [cited 2019 Aug 29]. Report No.: 50. Available from: https://www.oecd-ilibrary.org/social-issuesmigration-health/health-systems-institutional-characteristics_5kmfxfq9qbnr-en

9. OECD. OECD iLibrary | Health: Key Tables from OECD [Internet]. 2014 [cited 2019 Sep 16]. Available from: https://doi.org/10.1787/20758480.

10. Or Z, Bellanger M. France: Implementing homogeneous patient groups in a mixed market. In: Diagnosis-related groups in Europe Moving towards transparency, efficiency and quality in hospitals. Glasgow: Cambridge University Presfrance; 2011. p. 221-41.

11. Slabkiy GO, Rogach IM, Smirnov MM, Zhornyk VV. Financing model of healthcare institutions based on the example of France within the T2A system. Economy and legislation of health care. 2018;(2 (8)):59-63. [in Ukrainian]

12. Geri-Trial C, Mas C, Guibon O. Programme de médicalisation des systèmes d'information : valoriser les séjours des patients porteurs de plaies. Rev Francoph Cicatrisation. 2017 Apr;1(2):61-4.

13. Geissler A, Scheller-Kreinsen D, Quentin W, Busse R. Germany: Understanding G-DRGs. In: Diagnosis-related Groups in Europe: Moving Towards Transparency, Efficiency and Quality in Hospitals. Glasgow: Open University Press; 2011. p. 243-71.

14. Tuschen KH, Trefz U. Krankenhausentgeltgesetz. Komment Mit Einer Umfassenden Einführ Vergüt Station Krankenhausleistungen Stuttg Kohlhammer. 2004;

15. Neubauer G, Pfister F. DRGs in Germany: Introduction of a comprehensive prospective DRG payment system by 2009. In: The Globalization of Managerial Innovation in Health Care. Cambridge: Cambridge University Press; 2008.

16. Czach K, Klonowska K, Swiderek M, Wiktorza K. Poland: the Jednorodne Grupy Pacjentów - Polish experiences with DRGs. In: Diagnosis-Related Groups in Europe: Moving towards transparency, efficiency and quality in hospitals. Glasgow: Cambridge University Press; 2011. p. 359-80.

17. Kuszewski K, Gericke C. Health care systems in transition: Poland. Copenhagen, WHO Regional Office for Europe on behalf of the European Observatory on Health Systems and Policies; 2005 p. 130.

18. Stepurko T, Pavlova M, Gryga I, Murauskiene L, Groot W. Informal payments for health care services: The case of Lithuania, Poland and Ukraine. J Eurasian Stud. 2015 Jan;6(1):46-58.

19. Kozierkiewicz A. Jednorodne grupy pacjentów. Przewodnik po systemie. Nar Fundusz Zdrowia-Cent Publ House Wars. 2009.

20. Gaal P, Szigeti S, Csere M, Gaskins M, Panteli D. Hungary health system review. Health Syst Transit. 2011;13(5):1-266.

21. Health Consumer Powerhouse. Euro health consumer index. 2015. Health Consumer Powerhouse; 2015.

22. Maylath E. DRGs in der psychiatrischen Krankenhausfinanzierung am Beispiel Ungarns. Gesundhe.tswesen. 2000;62(12):633-45.

23. Evetovits T. Paying hospitals by DRGs: case-study from Hungary Bangkok: Joint Learning Network; 2010.

24. Gaal P, Stefka N, Nagy J. Cost accounting methodologies in price setting of acute inpatient services in Hungary. Health Care Manag Sci. 2006 Aug 1;9(3):243-50.

25. Cots F, Chiarello P, Salvador X, Castells X, Quentin W. DRG-based hospital payment: Intended and unintended consequences. In: Diagnosis-related Groups in Europe: Moving Towards Transparency, Efficiency and Quality in Hospitals. Glasgow: Cambridge University Press; 2011. p. 75-92.

\section{Стаття надійшла до редакції: 25.10.2019 р.}

